\title{
РАД - НЕРАД / КОНВЕНЦИОНАЛНИ СУД У СИСТЕМУ ВРЕДНОСТИ У СРПСКОМ ЈЕЗИКУ И КУЛТУРИ**
}

\begin{abstract}
У раду се разматрају фразеолошке парадигме које се формирају око социјално-утилитарне вредности рад и антивредности нерад у српском језику. Најпре се потврђује релевантност дијаде рад - нерад помоћу етнографског материјала, а потом се класификују и представљају поједине аксиологеме фразеолошко-паремиолошког материјала.

Кључне речи: аксиологема, аксиолошка парадигма, слот, рад, одмор, нерад.
\end{abstract}

1. Језик, као репрезент културе, чува и изражава систем, како вечних, животних вредности тако и оних друштвених, које постоје у различитим периодима развоја одређеног социума. Када се говори о проучавању односа категорија вредности и антивредности у науци о језику, нарочито у фразеологији, уочљиво је да се у радовима последње деценије јављају нови термини: аксиологема, лингвокултуролошка вредност, лингвоаксиологија, аксиолошка фразеологија, аксиолошки фразеологизми, аксиолошка информащија итд'.

1.1. У научним истраживањима у оквиру националних аксиологија вредност се одређује као „значење објекта за субјекат”. То значење може бити позитивно или негативно, те вредност има биполарну структуру: свакој вредности одговара антивредност (Гибатова 2011: 128). Поимање вредности изражава неколико функција у механизму живота: координирајућу (између човека и предметног света), стимулативну (усмерену на активност, делатност), дидактичку и регулативну (прескриптивну) (исп. Арутјунова 1999: 896). Вредности представљају и социјално-психолошке идеје и погледе на

\footnotetext{
*natasa.vulovic@isj.sanu.ac.rs; nativa8@gmail.com

** Овај рад настао је у оквиру пројекта 178009 Лингвистичка истраживања савременог српског језика и израда Речника српскохрватског књижевног и народног језика САНУ, који финансира Министарство просвете, науке и технолошког развоја Републике Србије.

${ }^{1}$ Рад представља наставак аксиолошког истраживања представљеног на Међународном научном скупу Научни састанак слависта у Вукове дане 2017. године у Београду.
} 
свет, које је етнички колектив априори одредио као нешто добро, исправно или пожељно, што би требало да служи као образац за стремљење и васпитавање у оквиру одређене друштвене заједнице.

1.2. Аксиологеме су класификоване као јединице којима се изражавају основне конвенционалне вредности и антивредности (животне, хедонистичке, социјално-утилитарне, морално-етичке, материјалне, когнитивне, емоционалне, религијске) кодиране у сазнању, култури и језику једног, у овом случају српског социума. У досадашњим концепцијама фразеолошких речника представљају се у оквиру одабраних основних, базичних дијада: живот - смрт, здравље - болест, срећа - несрећа, домовина (своје) - туђина (туђе), рад - нерад (лењост), богатство - сиромаштво, памет - глупост, истина лаж, смех - плач, рај - пакао. Аксиолошку парадигму формирају скупови аксиологема формирани према утврђеним параметрима, који су међусобно супротстављени, а обједињени према постојању позитивног (одобравајућег) или негативног (непожељног) аксиолошког вектора (в. Вуловић 2018: 292). Тај аксиолошки вектор који је позитиван или негативан може се мењати у процесу фразеологизације. Ова парадигма има слотну структуру, која се одликује флексибилношћу, а то зависи од фразеолошког материјала. Унутар поменутих хиперонима (вредности / антивредности) успостављају се хипоними, слоти (Бајрамова 2011: 12), односно, у оквиру одређених дијада подразумевају се, обухватају се и други семантички хипоними, али уз ограничења, регулисана применом семантичких параметара.

2. У овом раду испитаће се изражавање социјално-утилитарних категорија Рад. Труд. - Одмор. - Нерад. Лењост. у српском језику и култури. Примарно значење лексеме рад у описном речнику српског језика јесте „свесна људска активност, делатност чији је циљ постизање корисног учинка” (РС 2011). Појам рад садржи значења општедруштвеног (социјално-друштвеног) и корисног (утилитарног). Основно значење лексеме нерад је „одсуство физичке или духовне активности, физичка или духовна неактивност, беспосличење, беспослица, дангуба" (Р. САНУ).

2.1. При одређивању слота, слотова у оквиру дијада вредности/антивредности у карактеролошкој слици српског социума неопходно је укључити и поједине резултате етнографско-антрополошких истраживања текстова старих епитафа као описа личности на надгробницима, који садрже карактеролошки опис народа, његове вредности, потребе и стремљења. ${ }^{2}$ Као извор су послужили објављени текстови епитафа са надгробних споменика шумадијско-чачанског округа и (југо)западних села Србије, које је забележио Радојко Николић ${ }^{3}$ на теренским истраживањима и објавио у монографији Сељакова душа на камену. Специфичност епитафа на том простору

\footnotetext{
${ }^{2}$ При сличним истраживањима, лингвисти истичу важност резултата дијахронијских истраживања у језику, дакле дела писаних корпуса, јер сазнања о ономе што је било вредновано у прошлости чине механизам формирања културолошких вредности (Титкова 2003: 85).

${ }^{3}$ Књижевник, професор и педагог 25 година је прикупљао и проучавао натписе и цртеже са споменика у селима западне Србије. Завршио је српскохрватски језик и југословенске књижевности на Филолошком факултету у Београду, као и студије психологије на Филозофском факултету у Београду. Објавио је неколико монографија посвећених тој тематици и више радова.
} 
Србије јесте у томе што се текстови издвајају по својој дужини, садржају и јединственим описима карактеристика личности покојника. Консултовани корпус чине текстови старих споменика, јер је временом дошло до нестанка исказивања личних особина покојника на тај начин, тачније, ишчезла је та друштвено-психолошка потреба. Они нам служе као tabula picta у односу на фразеолошку ексцерпирану грађу, у овом случају ону о изражавању рада, нерада, лењости. Питање тачности, истинитости података није битно, јер је све у њима на посебан начин истинито, тј. вредности су приказане онакве какав човек јесте и, свакако, какав би желео да буде, народ у стварности, жељи, тежњи, а то је оно што омогућава увид у вредносну аксиолошку слику света српског етноса. Једна од таквих важних вредности јесу рад и стварање, као друштвеноморална особина најчешће на епитафима изражена синтагмама добар радник, трудољубив радник, великорадни житељ, добар радин и кућаник, врли домаћин, потом именицама раденик, радениия, трудиои и сл., придевима великорадан, трудољубив, утруђен и др. (Николић 2018: 350-352).

2.2. На текстовима споменика забележено је много неутрудних радника, који су цео живот настојали да нешто опосле, а ниједне речи нема о доконим залудњацима, дангубама и сл. Антивредности које се наводе епитафима тичу се законопреступника: убица, хајдук, лопов и сл., Готово сваки неморалан и нечовечан поступак је на неки начин бојкотован и осуђен (в. Николић 1991: 45). Тако се суд о лењости експлицитно не износи, као што ниједан домаћин стечевник није постао неко ко успева непоштеним делатностима. Уз осведоченог радника су употребљавани епитети: добар, признат, вредан, неуморан, врли, одличан, особит, велики, великорадан, много добар, поштен и узорит и др. На неколико споменика забележен је благослов за раднике: Ко год радио, Бог му помогао, док је једна домаћица себи за живота исклесала: Радила сам, Бог ми помогао (исп. Николић 1991: 56). Радом се стицао друштвени углед и уважавање, а радишност је подразумевала својство поштења, марљивог, упорног, тачног, доследног, прегалачког човека. Радиност је сматрана карактерним својством, а особит раденик „човечним човеком”. У Вуковом Рјечнику радник у Србији је „човјек који ради пољски рад” (Вук Рј.), а такав се и описује на споменицима као радљив и трудољубив, што је секундарно значење лексеме радник у једнотомном Речнику српскога језика „онај који се претежно бави физичким радом, особа која обавља физичке послове у индустрији, занатству, трговини и која за своју утрошену енергију прима плату" (РCJ 2011).

2.3. Од десетак одлика личности којима се стицао углед и поштовање уважен глас и сл. међу првим вредностима (после човечности, људскости) су труд и рад (потом доброта, праведност, поштење, памет, мајсторлук, способности, знања и умећа, стечено имање и др.), резултати који се истичу као стечени личним залагањем, не наследством или како другачије. Важно је рећи да се углед (независно од големашког положаја) стицао на основу моралних и радних способности, ретко за богатство и имање, осим уколико је стечено, личним залагањем. Очекивано, текстови на споменицима мушкараца су опширнији, детаљнији у описима, што је условљено патријархалним начином 
живота. Тако се синтагма „добра радница” појављује на натписима после 1900. године.

2.4. Консултовани контролни етнографски материјал потврдио је релевантност дијаде рад - нерад у културолошко-антрополошкој слици света српског народа. У наставку ће бити представљено изражавање ових аксиолошких категорија у фразеолошком корпусу српског језика.

3. Као што је већ истакнуто, вредности рад и труд комбинују у себи схватања заједнице (социјални аспект) и користи (утилитарни аспект). Лексема труд има примарно значење „напрезање, напор који се чини при вршењу неког умног или физичког рада" (РСЈ). У филозофији утилитаризма, циљ човековог рада и јесте извлачење индивидуалне и/или опште користи, наравно етичким средствима, уз битне функције рада: економску, социјалну, престижну и психолошку. Унутар социјално-утилитарних вредности и антивредности Рад. Труд. - Одмор. - Нерад. Лењост. издвајају се слоти, слотови, као хипоними. Паремиолошки материјал ће бити класификован под засебним слотовима.

3. 1. У складу с наведеним, биће наведени слоти фразеолошке парадигме социјално-утилитарне вредности Рад. Труд.

Почети радити; почетак посла; латити се посла. У оквиру овог слота забележили смо око двадесет аксиологема, на пример: бациити се на књигу, будак у крчевину (ледину) забити; будак у руке (узети) (,запети, почети нешто напорно радити"); гојити прасе уочи Божића (тражити печенииу уочи Божића) („почињати посао када је већ касно”), загрејати столииу; заорати прву бразду (,бити пионир у неком послу”); латити се рала и мотике; опљунути дланове; пљунути у длан, шаке и др.

Вредан, добар радник. Неколико аксиологема спада у ову подгрупу и све имају поредбену (тематско-рематску) структуру: вредан као пчела (пчелиияа; мрав; ирв); радан као кртица; ради као машина (луд, блесав) и сл.

Добар мајстор, изврстан стручњак, веома квалификован у послу. Десетак аксиологема изражава ову поткатегорију: бити глава у неком послу, бити добро поткован; бити мајстор свог заната; знати ђавола на леду потковати; имати златне руке; испећи занат и др.

Много радити, обављати тежак рад. Неке аксиологеме које припадају овој групи су: дошла душа у подгрлац (под грло) некоме; душа стиже до јабучиие; извлачити (вадити) кола из блата („напорно радити, запињати у неком послу”); истегнути душу („намучити се радећи тежак посао”); јести горак хлеб; радити као роб (црнаи), радити као коњ (стока) итд.

Лак посао. Овде бележимо неколико аксиологема: иде глатко (некоме) као попу код олтара; ићи од руке (некоме); тражити хлеба без мотике (,желети, тражити начина да се лако, без много рада и труда дође до зараде, до средстава за живот".

Бити способан у раду, продуктивно, прецизно радити: држати три ћошка куће; метати, стављати тачку на јоту; од једног динара два (nет) правити итд.

Радити енергично, са одушевљењем: ухватити бика за рогове. 
Осећати задовољство обављеним послом: накривити капу.

Лоше обављати посао; не знати радити свој посао: бити дупе глава; дати јариу да чува купус; радити нешто левом ногом; радити (обављати) нешто као мачка репом и сл.

Радити узалудан, бекористан посао: ветар у врећу хватати; воду решетом захватати; длаке гулити; докон поп и јариће (говеда) крсти; дрва у иуму носити; истеривати мачку кроз димњак; млатити глогиње; мусти јариа над решетом (у решето); радити за бабино брашно итд.

Радити за себе: бити сам себи господар; бити ияар на своме; радити за своју браду и др.

Експлоатисати некога; радити за другог који користи резултате рада: бити у нечијим шапама; вадити (вући) за некога (вруће) кестење из ватре; пити (сисати) некоме крв на памук (сламку); кројити некоме гаће; упрегнути некога у јарам и сл.

Оспособити некога да ради: дати некоме хлеб у руке

Спречавати нечији рад, успех у раду: гурати (стављати) некоме штап у точкове, подлити воду некоме; подметати (стављати) некоме клипове под точкове (у точкове) и др.

Обављати посао на брзину: (u) на врат и на гњат; наврат-нанос и сл.

Помагати некоме у раду; помоһ при раду: бити на (при) руци; бити нечија десна рука; држати се зубима за ветар („бити без помоћи”) итд.

Плаћање рада: борба за насушни хлеб; радити за кору хлеба; радити за шаку долара и сл.

Радити поштен, частан посао: бити чист као суза у нечему; бити чиста чела; бити чистих прстију (руку) и др.

Обављати ризичне, сумњиве, нелегалне послове: авиони-камиони; бавити се свим и свачим; ћорав посао итд.

3.2. Лексема одмор има примарно значење „прекид активности (физичке или интелектуалне) ради надокнаде утрошене снаге, починак, мировање”. Категорија Одмор. је према семантичком садржају блиска вредности рад, јер подразумева осећај олакшања после тешког или напорног посла, а такође и задовољства после обављеног, решеног и сл. посла. Њу у српском језику изражава аксиологема дахнути душом (душицом).

3.3. Антивредност Нерад. Лењост. изражена је мањим бројем аксиологема. Такође су малобројнији слоти фразеолошке парадигме социјално-утилитарне антивредности Нерад. Лењост.

Не радити ништа: бројати звезде на небу; дувати у длан (дланове, прсте); живети од ваздуха; јести хлеба без мотике; красти Богу дане (божје дане); седети скрштених руку и др.

Бити лењ: добити нешто на тацни (тањиру); лези хлебе да те једем; лења буба; лењ као трут (магараи, крава, клада) итд.

Избећи посао: измакнути (измаћи) своја леђа; не дићи дупе (гузииу) и сл.

Бити без посла: бити на улици; отићи на буњиште и др. 
3.4. Аксиологеме и морал у пословицама и изрекама о труду, раду, одмору и нераду, лењости класификују се према гномском карактеру. Биће наведен по један илустративан пример. Слоти паремиолошке парадигме социјално-утилитарне вредности Рад. Труд. су:

Рад као средство изражавања:

Ради као да ћеш 100 година живети, а моли се богу као да ћеш сутра умрети.

Рад је повезан с трпљењем, усрдношћу, вољом и жељом:

Кад сиромах кућу гради и камен се зноји.

Рад је неотуђиви део живота:

Док смо живи радимо, кад умремо лезимо.

Рало и мотика свет храни.

Рад доноси срећу, радост и задовољство:

Срећа се радом стиче.

Ваљь запети, па запевати.

Рад доноси материјално благостање:

Ко ради не боји се глади.

У ковача ирне руке, ал'је бела погача.

Резултат рада зависи од уложеног труда:

Нема хлеба без мотике.

Рад треба радити квалитетно:

Само мудра глава стотину руку има.

У раду је знање, искуство:

Ако сам гадљива, оно сам радљива.

Успех долази само с резултатима рада:

Како радила, тако се хранила.

Успех у раду је повезан с временом:

Тиха вода брег рони.

Што је брзо, то је и кусо.

Успех не долази ономе ко се не брине за своје дело:

Лакие је стећи него сачувати.

3. 5. Слоти паремиолошке парадигме социјално-утилитарне антивредности Нерад. Лењост. су:

За лењивца труд није вредност:

Беспослен Мујо фишеке савија.

Нерад и лењост не доносе радост, срећу:

Паук по извећу скупља јед, а пчела мед.

Лењивац је достојан презрења:

Беспослица и лењак не може нигда угодан бити.

Лењ човек у свему и за све:

Кад се лењ накани, сав свет попали.

Лењост води у сиромаштво:

Прасаи чист никад претио.

Вредном човеку и природа помаже, а лењивца не воли: 
Радиши Бог помаже.

Ко ради наради, Бог не брани.

4. У анализи аксиолошке парадигме везане за дијаду рад - нерад, отварају се бројна питања, на која треба у будућим истраживањима понудити релевантне одговоре. Уочава се обимност фразеолошке парадигме под слотом радити, обављати тежак посао, много радити, као и обављати узалудан посао. Посебно се истиче формирање карактеристичних слота који се тичу дијаде поштен / непоштен човек, а то су: обављати ризичан, сумюив по$c a о$, као и радити свашта. Свакако треба обратити пажњу на прагматичко-оцењивачки маркиране јединице, посебно у паремиолошком материјалу које би остале ван једнообразно форматираних слота вредности и антивредности, а тичу се семантички неутралних, иронијских, напоредно-поредбених или суспектних форми, нпр. Ако сам гадљива, оно сам радљива, Кад се лењ накани, сав свет попали, Бог помаже лежаку као и тежаку и сл. Овоме треба посветити пажњу у даљем раду, како би фразеолошка слика конвенционалног суда о раду, труду, одмору, нераду и лењости била што потпунија и самим тим одговарајућа tabula signa културолошкој слици социјално-утилитарних вредности у српској традицији.

\section{ИЗВОРИ}

Караџић 2002: В. Караџић, Библија. Стари и Нови завет, Београд: Leо commerc.

Матешић 1982: J. Matešić, Frazeološki rječnik hrvatskoga ili srpskog jezika, Zagreb: Školska knjiga.

Оташевић 2012: Ђ. Оташевић, Фразеолошки речник српског језика, Нови Сад: Прометеј.

PМС: Речник српскохрватског књижевног језика (I-VI), Матица српска, Нови Сад - Загреб, 1967-1976.

РСАНУ: Речник српскохрватског књижевног и народног језика (1-20), Институт за српски језик САНУ, Београд, 1959- .

PCJ: Речник српскога језика, Матица српска, Нови Сад, 2007.

\section{ЛИТЕРАТУРА}

Арутјунова 1999: Н. Д. Арутюнова, Язык и мир человека, Языки русской культуры, Москва: Наука, 894-899.

Бајрамова 2011: Л. К. Байрамова, Аксиологический фразеологический словарь русского языка, Издание 2-е, Казань: Центр инновационных технологий. 
Бајрамова 2013: Л. К. Байрамова, Отражение в библейских текстах ценностей и антиценностей и отсутствие некоторых их корреляций с эпизодами современной жизни, Филологические науки. Лингвистика, Казань, $136-140$.

Вуловић 2018: Н. Вуловић, Аксиологеме као одреднице у фразеолошком речнику, Научни састанак слависта у Вукове дане, 47/1, 291-300.

Гибатова 2011: Г. Ф. Гибатова, Аксиология в языке, Вестник ОГУ, бр. 2, Оренбург, 127-132.

Николић 1991: Р. Николић, Сељакова душа на камену, Горњи Милановац: Дечје новине.

Николић 2018: Р. Николић, Камена књига предака, Чачак: Народни музеј.

Титкова 2003: О. И. Титкова, О перспективах лингвистического исследования рекуррентных единиц лексикона, Филологические науки, 2, 79-86.

\author{
Наташа С. Вулович
}

\title{
РАБОТА - БЕЗДЕЛЬЕ / КОНВЕНЦИОНАЛЬНАЯ ОЦЕНКА В СИСТЕМЕ ЦЕННОСТЕЙ В СЕРБСКОМ ЯЗЫКЕ И СЕРБСКОЙ КУЛЬТУРЕ
}

Резюме

Предметом исследования в настоящей работе являются аксиологическая фразеологическая парадигма ценности и антиценности работа / безделье в сербском языке и сербской культуре. Конвенциональная оценка маркирует слотовую структуру фразеологической парадигмы Работа. Труд. - Отдых. - Безделье. Лень (например: будак у руке (узети), радити као коњ, бити лењ као трут и. тд.).

Ключевые слова: фразеология, аксиология, аксиологическая парадигма, работа, безделье, слот(ы). 